\title{
Freedom as Non-domination and Democratic Inclusion
}

\author{
Ludvig Beckman' ${ }^{1} \cdot$ Jonas Hultin Rosenberg ${ }^{2}$
}

(C) The Author(s) 2017. This article is published with open access at Springerlink.com

\begin{abstract}
According to neo-republicans, democracy is morally justified because it is among the prerequisites for freedom as non-domination. The claim that democracy secures freedom as non-domination needs to explain why democratic procedures contribute to non-domination and for whom democracy secures nondomination. This requires an account of why domination is countered by democratic procedures and an account of to whom domination is countered by access to democratic procedures. Neo-republican theory of democracy is based on a detailed discussion of the former but a scant discussion of the latter. We address this lacuna by interpreting the two most influential principles of inclusion, the all-subjected principle and the all-affected principle, in light of neo-republican commitments. The preliminary conclusion is that both principles are able to capture relations of domination between the democratic state and the people controlled by it in the relevant sense. Yet, the state has virtually unlimited powers to control residents, but only limited powers to interfere in the lives of non-residents. Republican aspirations are therefore more in tune with the all-subjected principle according to which only residents in the territory of the state should be granted rights to political participation.
\end{abstract}

Keywords Neo-republicanism · Non-domination · Democracy · Inclusion · Residents

Ludvig Beckman

Ludvig.beckman@statsvet.su.se

Jonas Hultin Rosenberg

jonas.hultin_rosenberg@statsvet.uu.se

1 Department of Political Science, Stockholm University, 10691 Stockholm, Sweden

2 Department of Government, Uppsala University, Box 514, 75120 Uppsala, Sweden 
People sometimes argue that democracy is the best type of political regime either because it contributes to human development or because it alone is consistent with equal respect and concern for all citizens. According to neo-republicanism, these reasons are both mistaken. Democracy is justified because it is among the prerequisites for freedom. This is the core of the neo-republican theory of democracy developed and defended by Pettit $(1997,2012)$. The basic premise of neo-republican democracy is the ideal of freedom as non-domination; following neo-republicanism, democratic rights offset domination by placing the exercise of the public powers of the state under popular control.

The claim that democracy secures freedom as non-domination needs to explain why democratic procedures contribute to non-domination and for whom democracy secures non-domination. Pettit's neo-republican theory of democracy is based on a detailed discussion of the former but a scant discussion of the latter. As noted by Sager (2014, p. 189) 'neo-republicans have not devoted enough attention to the conundrum of democratic inclusion'. Thus, the neo-republican theory of democracy needs an account of democratic inclusion.

The lack of attention to the problem of democratic inclusion in neo-republican thought is curious given the emphasis on the status of citizenship in the republican tradition from which it emanates. A basic tenet of republicanism is that we ought to take citizenship more seriously and that the proper estimate of the rights and duties of the citizen is key to the realization of political freedom and justice. In contrast to 'the subject', who is the mere object of political power, 'the citizen' is both ruler and ruled (Peacock 1995, p. 39; Dagger 2002). But who is entitled to be a citizen following neo-republicanism, if by a citizen we mean the bearer of rights to political participation?

The work of Pettit provides some clues. Following Pettit (2012, p. 75), political rights should extend to 'all the more or less settled residents of a state'. Understood as rules for democratic inclusion, the implication is that the residents of democratic states should be included in the demos. However, these rules do not themselves constitute principles for democratic inclusion in the sense that they do not explain why democracy requires the inclusion of residents. In addition, the claim that residents should be included does not provide any guidance as to whether nonresidents ought to be included or excluded.

Recent followers of neo-republicanism have invoked its basic tenets to support claims to inclusion. For example, Benton (2014) argues that neo-republican freedom is better suited to explain the rights of 'denizens' (resident non-citizens) than liberalism and other dominating perspectives. Similarly, citizenship laws and suffrage restrictions are criticized by Fine (2014) and Hovdal-Moan (2014) on the basis of neo-republican conceptions of freedom. But the task of applying neorepublican standards to political institutions is not equal to the task of elaborating what the substance of these standards should be.

We address the political rights of both resident non-citizens and non-residents in neo-republican democracy. In addition, the paper aims to identify a conception of democratic inclusion that is both reasonable and that fits with neo-republicanism. In assessing the reasonableness of principles of democratic inclusion, we take into account recent debates on the all-affected principle and the all-subjected principle 
(Miller 2009; Näsström 2011; Erman 2014; Valentini 2014; Beckman 2008; Owen 2012). In assessing the fit with neo-republicanism, the picture is less clear-cut as previous writers make conflicting assumptions; some take for granted that freedom of non-domination calls for the inclusion of everyone affected (Schuppert 2014, p. 139; Benton 2014, p. 410), whereas others reason on the premise that only those subject to the state should be included in the neo-republican state (for example Sager 2014; Owen 2014, p. 98). Our position on democratic inclusion should be consistent with both general developments in democratic theory and the basic commitments of neo-republicanism.

The first section outlines some of the basics of the neo-republican conception of democracy and the place of democratic inclusion in this account. The second section formulates a neo-republican interpretation of the all-subjected principle. The third section formulates a neo-republican version of the all-affected principle. The fourth section concludes the paper by developing reasons why the proposed conception of the all-subjected principle is to be preferred as the neo-republican conception of democratic inclusion.

\section{Democracy and Freedom as Non-Domination}

Democratic inclusion can be justified by reference to the value of the vote as a 'personal resource or good' (Goodin and Tanasoca 2014; López-Guerra 2012). Neorepublicans justify democratic inclusion in other terms, however, since they claim that freedom should be our primary concern.

Neo-republicanism shares with liberalism the idea that freedom is incompatible with subjection to the will of others. It differs from liberalism, however, in holding that freedom is the freedom of persons and not the freedom to choose (Pettit 2007). Following the 'proto-liberal' Hobbes (1994 [1668], 21.2), freedom requires that a person is not frustrated in her pursuit of his goals: 'a free-man is he that, in those things which by his strength and wit he is able to do, is not hindered to do what he has a will to'. Following Isaiah Berlin, a person is free in the liberal sense if there is no interference from others; freedom of choice means that any option should remain available, chosen as well as unchosen options (Pettit 2011, p. 704).

By contrast, neo-republican freedom as non-domination holds that a person is free if others are not in a position to subject him or her to their will. Freedom as nondomination is not guaranteed either by the Hobbesian notion of freedom as nonfrustration or by Berlin's conception of freedom as non-interference (Pettit 2007, 2012). A person can be subject to domination even though she is not interfered with. The paradigmatic example involves a benevolent slave-owner who does not interfere with his slaves, but is in a position to do so. A more relevant example here is the relation between the state and its subjects. From the perspective of non-frustration and non-interference, what limits freedom is state action vis-à-vis its subjects. Hobbes (1994 [1668], 21.18) famously argues that in cases where the sovereign has prescribed no rule, there the subject hath the liberty to do, or forbear, according to his own discretion'. But, from the perspective of non-domination, freedom is limited if the state is in a position to interfere arbitrarily. Freedom as 
non-domination requires that the state is no longer in a position to interfere with its subjects or if its subjects control the state. ${ }^{1}$

Non-interference (and non-frustration) is not necessary for non-domination. There are instances of interference that do not imply domination. Think again of the relation between the state and its subjects. The state usually limits the choices of those subjected to it. It removes and it replaces options by imposing obstacles, penalties and rewards. Does this necessarily lessen the freedom of those subjected to these limitations? Liberals who understand freedom as non-interference think that it does. Neo-republicans who understand freedom as non-domination believe that this is an open question. If state interference is arbitrary (Pettit 2007), uncontrolled (Pettit 2012) or alien (Pettit 2008b) it lessens the freedom of those interfered with. If state interference is controlled by those subjected to it, then it does not lessen freedom (understood as non-domination). ${ }^{2}$

There is, thus, domination without interference and interference without domination. If we are interested in freedom and unfreedom in the exercise of political power, the objective should not be to limit the exercise of political power but to organize the exercise of political power so that domination is limited.

To explain the difference between interference and domination, Pettit distinguishes between 'uncontrolled control' and 'controlled control'. An agent A is dominated if he is subjected to uncontrolled control by another agent B. An agent B has uncontrolled control over $\mathrm{A}$ if he is in a position to interfere with $\mathrm{A}$ and if $\mathrm{A}$ does not have recourse to any institutionalized means to control the position of B. In Pettit's words, this places $\mathrm{B}$ in a position where she 'has the unvitiated and uninvaded capacity to interfere or not to interfere [with A]' (Pettit 2012, p. 50). Pettit believes that political rights are essential requirements for controlled control; a necessary condition for freedom as non-domination is that people subject to public power are able to participate by the vote and by other means in the authorization of the government.

Democratic inclusion counteracts domination because it secures 'controlled control' by the subjects to public power as it provides them with the political rights necessary to contest the exercise of these powers. ${ }^{3}$ From the perspective of freedom as non-interference, there is no evident difference between benevolent dictatorship and democracy. Life under non-democratic government is in principle consistent with freedom as non-interference. A benevolent dictatorship could do better than democracy, according to liberal standards of non-interference (Pettit 2011). No such possibility seems open to adherents of freedom as non-domination. Although Pettit warns against the potential tyranny of the majority, and therefore favors strong constitutional safeguards, the major point is that freedom as non-domination requires opportunities to participate in the exercise of 'control' of public power. It is

\footnotetext{
1 As Pettit (2006, p. 302-304) argues, democratic control requires both authorial and editorial control.

2 In earlier writings Pettit held the view that interference is arbitrary only if it fails to 'track the interests' of the people interfered with. As noted by Blunt (2015, p. 15), Pettit has abandoned this view in more recent writings.

3 An objection to this claim is that the right to vote is barely sufficient for a single individual to contest the exercise of public powers. To the extent that the objection is valid, it applies to neo-republican justifications to democracy as well as to other accounts. For an attempted rejection, see (Jacob 2015).
} 
only by democratic rights that the people subject to public power have the capacity to control them and thus to evade domination. ${ }^{4}$ The consequent principle of democratic inclusion appears straightforward: everyone controlled by public power must be included in the demos in order to avoid domination.

Yet, the claim that 'everyone' subject to control by public power should be included remains vague and subject to several readings. Subjection to control can be understood either in terms of a person being affected or subject to coercion and/or the law. The substance of the neo-republican principle of democratic inclusion can only be determined by an attempt to decide which of these alternative readings that best corresponds to the requirements of freedom as non-domination.

\section{The All-Subjected Principle and Non-Domination}

As noted by Sager (2014), there are important similarities between the neorepublican position and the view that democracy requires political rights for everyone subject to coercive state power. The similarity derives from the neorepublican claim that people subject to a legal and political authority where they have no political rights represents a typical instance of domination. Conversely, freedom as non-domination is achievable only in a democratic state of popular control, where the opportunity to participate is 'available with equal ease to each citizen' (Pettit 2012, p. 169). The neo-republican reading of the all subjected principle seems particularly fit to explain the significance of two basic features of the ideal of freedom as non-domination: the imperative to minimize intentional or quasi-intentional interference ${ }^{5}$ and the claim that potential interference is inimical to freedom.

As noted above, interference violates freedom if and only if intentional; freedom as non-domination is concerned with the preconditions for political freedom, not with obstacles of nature. By contrast, law and public power are not forces of nature, but always have as their origin the intended decisions of various agents. Legislation and public policy deliberately seek to regulate the behavior of individuals and organizations in order to achieve identifiable ends. Intentionality is an inherent feature of public power. ${ }^{6}$

Second, people subject to public power count as subjects precisely because they remain vulnerable to revisions, expansions or contractions of the norms and actions that regulate their behavior. To be subject to public power is not, then, exhausted by the actual imposition of a coercive sanction. This is significant from a neorepublican perspective, as one of the defining elements of freedom as non-

\footnotetext{
${ }^{4}$ Some believe the connections between democracy and freedom as non-domination are even deeper (Rostbøll 2015). Others emphasize the centrality of freedom as non-domination in the liberal tradition (Urbinati 2012).

${ }^{5}$ Only intentional and quasi-intentional interference is relevant to neo-republicans. Interference is intentional or quasi-intentional when the interferer has a choice between interfering and not interfering (Pettit 2012, p. 49).

${ }^{6}$ This holds even on Hayek's (1973, p. 113) view that the law 'does not serve any purpose but the countless different purposes of different individuals'.
} 
domination is that it eschews dependency on the potential interference by other agents. The slave's unfreedom does not only reside in the fact of being subject to actual interference but consists also in the constant threat of being interfered with by the slave-owner.

If subjection to public power is a sufficient precondition for democratic inclusion, on the neo-republican account, a number of practical implications follow. To spell them out, we need to clarify the scope of public power. Doing this is not necessarily difficult as the enforcement of the law, by the state, is typically limited to a specific jurisdiction defined as the territorial domain where the authority of the state is recognized. So, if democratic inclusion depends on subjection to public power, and if the scope of public power is constrained by territorial jurisdiction, it evidently follows that political rights should be recognized only among people present within the jurisdiction. The normative conclusion is that all non-citizen residents should be included, because they are present in the jurisdiction, whereas the inclusion of nonresident citizens is not required and possibly proscribed. However, the precise normative implications of this account of democratic inclusion are not so obvious once the various meanings of subjection to public power are further analyzed. In what follows, we examine four distinct accounts of public power.

One view is that subjection to public power extends beyond the territorial borders of the state because of the ability of border regimes to coerce even people on the outside. As influentially argued by Abizadeh (2008), the coercive threats implied by restrictive border regimes do indeed seem to target outsiders. The threat communicated by border policies stems from the fact that they regulate the status and conditions for anyone with a preference for crossing the border, backed up by the threat that anyone who does not fulfill the conditions will be apprehended, detained and deported. It is important to ponder the sense in which border policies are coercive, following this analysis. As is recognized by Abizadeh (2008, p. 40), coercive power has several dimensions, including physical force. He nevertheless insists that the coerciveness of law 'inheres in the authorization of threat itself' (Abizadeh 2010, p. 123). Hence, the coerciveness of border regimes does not consist in the sanctions implemented against people, not even in the possibility of being the target of sanctions, as it derives primarily from the pressure exerted on outsiders by the authorities. In other words, in order to conclude that borders are coercive we must accept communicative threats as a primary sense of coercion. ${ }^{7}$ The point is that the implications of the all-subjected principle with respect to non-residents are more inclusive, provided that we understand 'subjection to state coercion' in a specific way. The reading suggested by Abizadeh is that anyone is subject to state coercion in the relevant sense if he or she is the target of a communicative threat by the authorities of the state.

Following a second view, a person is subject to coercion if and only if that person is subject to force (Morris 2012, p. 34) or compulsion (Hughes 2013, p. 234) or a broader range of phenomena that includes the use of violence, force or threats (Anderson 2010, p. 6). When coercion is understood in terms of force, it is not

\footnotetext{
7 This position is contested by Miller (2010). But see Saunders (2011, p. 61) for a critical assessment of both Miller and Abizadeh.
} 
immediately clear that restrictive border policies render outsiders subject to coercion. To submit that a person is forced implies that the person is compelled to behave in some way or another without having a choice. Force is typically exercised when the police haul a person into a police car or handcuff a person. Thus, in order for coercion as force to be manifest, it is not enough that a person experiences psychological pressure or that some options are made less attractive. When coercion is understood in terms of force, the subjects to coercion are compelled to do or abstain from doing certain things, in the sense that their volitional control is overridden. The significance of this notion is clear in relation to border policies, as people on the outside of the border are not subject to force. The communicative threat by $\mathrm{A}$ that force will be employed if $\mathrm{B}$ does $\mathrm{X}$ is not equal to the employment of force by A to B. The communication of threats does not equal exercise of force and, though border policies certainly do threaten outsiders, they do not subject outsiders to force.

The objection to this view is that residents in the territory of the state are rarely forced to conform to the law. Just like non-residents, state institutions force them only when they violate legal norms. There is no difference, then, between residents and non-residents as the employment of force is in both cases hypothetical.

Now, it is true that the correct sense in which residents are subject to public authority is by the fact that they are subject to force rather than forced. They are subject to force in the sense that the state apparatus stands readily available to enforce the law and the directives of the government at any time. Of course, the activation of force is at least partly conditioned by the behavior of the individual resident. Typically, residents are forced only if they violate the law. The point is, however, that residents are subject to force whether or not they violate the law. The capacity of the state to enact force remains the same for all residents. This is not true for non-residents. Non-residents are not subject to force because the state is unable to employ force beyond its territorial borders. They are only subject to force if and when they choose to enter the territory of the state.

This conclusion can be resisted by pointing out that states do not always restrict the use of force to their own territories. Some governments more often than others take military action against individuals or groups in foreign territories (Lubell 2010, p. 4). Surely, the targets of military action by a foreign state are subject to the use of force by that state. But then, if any state holds the capacity to use force beyond its territorial borders, it seems to follow that every outsider is potentially vulnerable to the use of force by any state. This conclusion seems irresistible if subjection to coercion equals subjection to force, and if subjection to force means being vulnerable to the employment of force.

On the other hand, this precise objection can be deflated by invoking the conditions for domination specified by Pettit. As made clear by him, a person is subject to domination by another only if the other has the capacity to interfere with his whereabouts 'without costs'. This qualifier is important as it explains why domination does not necessarily take place just because one agent is interfered with by another agent. If interference is costly, possibly because there are some institutions that attempt to protect us from interference from others, it follows that we are not dominated. Arguably, this is exactly what is happening when one state is 
interfering in the lives of individuals situated in foreign territories. States do have the capacity to resist such interference and there are potential sanctions available through international law. Hence, interference beyond the territory of the state is typically not costless and so not domination.

A more serious objection against interpreting coercion as force in the context of a neo-republication theory of democracy is that it does not appear congenial to neorepublican aspirations. Following Sager (2014, p. 192), republican freedom is a function of 'the institutions, norms, and laws that regulate the community'. The point is that there is a legal relationship between individuals and the state. Individuals are vulnerable to the dominating powers of the state because they are subject to binding legal norms. Following Sager's reading of the neo-republican ideal, it is by reference to the law and not by reference to either coercion or force that the state has the potential to dominate its subjects. The significance of legal norms helps explain why individuals are able to overcome the dominating effects of the state when they have rights to 'author' the laws to which they are subject. A single-minded concern with either force or coercion fails to account for what neorepublicans consider to be among the major sources of domination but also for what they take to be among the remedies of this condition. The neo-republican account of democratic inclusion should in other words be sensitive to the legal nature of the relationship between individuals and the state.

A third account of public power is provided by the legal reading of the allsubjected principle. The basis for such an account is the observation that any legal norm includes a legal imperative that it should be obeyed (Greenawalt 1987, chap. 2 ). The people targeted by the norms of the legal system are in other words subject to legal duties. The rationale for the view that political rights should extend to all subjects of the state is, therefore, that people who are subject to legal duties should be afforded corresponding legal rights to participate in deciding the substance of these duties.

Again, a problem for this version of the all-subjected principle is that the scope of legal duties appears hard to determine or, alternatively, is simply too extensive as they would include everyone. Many legal systems include legal provisions that explicitly apply outside of the territory of the state. According to the tax code of the United States, citizens are obliged to pay income taxes even if they are foreign residents. Some nations make specific activities a legal offense even when conducted abroad, such as child abuse, torture or participation in genocide. Other nations include provisions of universal jurisdiction for particularly serious crimes (Macedo 2006). In relation to such provisions, it seems that each person, irrespective of nationality or place of residence, would indeed count as a legal subject. ${ }^{8}$

In response, a distinction is required between being subject to the legal duty to obey a singular legal norm and the legal duty to obey the legal system as such. What distinguishes residents from non-residents is that the former, but not the latter, are

\footnotetext{
8 See further, Owen (2014) who argues that the extra-territorial effects of law are democratically pertinent only for non-resident citizens and only in relation to laws that regulate their rights as nonresident citizens as they arguably have 'a legitimate interest in legal changes in their relationship to the country of citizenship’ (Owen 2014, p. 98).
} 
subject to the legal duty to obey whatever legal norm is promulgated as valid within the legal system. Pettit (2012, p. 76) occasionally describes citizens as subjects to 'the order of law', indicating that subjection to the legal system is the more relevant condition from a neo-republican standpoint.

On the other hand, it might be held that we need to distinguish between the actual and the potential scope of the legal order. The extra-territorial scope of legal norms in a given legal system may currently be limited. Arguably, however, the legislature has the power to extend the prescriptive dimensions of jurisdiction extra-territorially as it pleases. Hence, every non-resident is potentially vulnerable to the legislative powers of any state and therefore at least potentially subject to legal duties. Since by republican standards, freedom is violated by potential as well as actual interference, it follows that everyone everywhere is dominated; everyone is subject to domination by every legislative body everywhere.

The extent to which this represents an objection to this version of the allsubjected principle is uncertain. The neo-republican might bite the bullet and conclude that everyone is in fact subject to the legislative powers of every legislative body. This observation would offer inspiration for a neo-republican argument for trans-national structures of democratic governance and political rights that has so far gone unnoticed.

A more serious objection to the legal interpretation of the all-subjected principle is that subjection to legal duties is insufficient for domination to obtain. Legal duties to obey legal norms are imperatives. But the mere fact of being the target of legal imperatives neither removes or replaces options; from the mere fact that the option to do $\mathrm{X}$ is contrary to a legal norm it does not follow that the option of doing $\mathrm{X}$ is either removed or replaced. Pettit $(2012$, p. 51) considers as the standard case of replacing options the imposition of penalties on doing $\mathrm{X}$. Penalties transform options by adding a cost to them; the imposition of a legal penalty against doing $\mathrm{X}$ replaces the option to $\mathrm{X}$-minus. Yet, if legal penalties are required for options to be replaced, it follows that subjection to legal imperatives is not sufficient for options to be replaced. The point is that replacement of options by means of penalties is premised on the ability of the state to employ coercion. Thus, the capacity to enforce the law by coercive means is among the necessary conditions for domination by the state. $^{9}$

The conclusion is that there is a fourth conception of public power. It represents the conjunction of two distinct propositions, i.e. the claim that subjection to public power follows only from subjection to legal norms and the claim that an agent is subject to domination by another agent only if the other agent has the capacity to remove or replace the options available to the first agent by the use of coercion. Together, these are two necessary and sufficient conditions for democratic inclusion (Beckman 2014). The neo-republican conception of inclusion applies to anyone subject to legal duties if they are backed up by the capacity of the state to enforce

\footnotetext{
${ }^{9}$ Not all legal norms entail imperatives to be obeyed. As Hart, Raz and others have shown, the law confers secondary rules, power rights and immunities that regulate the creation of legal norms and that do not impose any duties.
} 
them. A virtue of the fourth view is that it captures both the legal and the coercive aspects of the state, without reducing the one to the other. It also serves to clarify the neo-republican ideal of democracy by identifying its dual aspirations towards freedom through the law and freedom from arbitrary coercion.

The discussion so far has identified four distinct readings of the all-subjected principle that point at two important features that we should expect from a neorepublican account of democratic inclusion. The first is that the legal relationship between citizens and the state needs to be accounted for. Democratic rights are not concerned with the regulation of brute force but serve the aim of regulating the legal and ordered structures of a political society. The second is that domination only takes place where options are potentially replaced or removed. It is not sufficient to be merely in a legal relationship.

\section{The All-Affected Principle and Non-Domination}

In the previous section, we proposed a revised understanding of the all-subjected principle that is more in tune with neo-republican commitments and less vulnerable to standard objections. This section will suggest a neo-republican interpretation of the all-affected principle that gives another answer to the question of why residence is important. We will thus argue that not only the former but also the latter could be interpreted in a way so that it fits the neorepublican conception of democracy.

The idea that freedom as non-domination requires democratic inclusion of all and only those relevantly affected is not an entirely novel one. Ian Shapiro argues that 'if democracy is about structuring power relations so as to limit domination' then 'the claim to a democratic say in collective decisions, whether or not one is a citizen, rests on the causal principle of having a pertinent affected interest' (Shapiro 2003, p. 52). Others have challenged the view that the neo-republican conception of democracy requires inclusion of everyone affected (Owen 2012; Sager 2014). Owen (2012) explicitly challenges Shapiro's view, arguing that democratic inclusion is not the appropriate response to all instances of interference. Similarly, Sager (2014, p. 195) argues that not everyone that is affected by political decisions is vulnerable to domination, so democratic inclusion is not always the appropriate response. The basic idea behind this argument seems to be that democratic inclusion is the appropriate response to some instances of uncontrolled interference but not to others. This idea will be addressed in the next section. Sager (2014, p. 196) also argues that when those with an affected interest ought to be included this is so not because they have an affected interest but because they are vulnerable to domination if they are excluded. This argument is based on an overly narrow understanding of the all-affected principle, which will be challenged below. We agree with Sager that the standard version of the all-affected principle fits poorly with neo-republican democracy but for other reasons than those discussed by him. We argue against Sager that there are versions of the principle that seem to fit better with this conception. 
To fit with the neo-republican conception of democracy we should think of 'affected' as 'interfered with'. ${ }^{10}$ Democracy enables people to control practices of state interference and therefore to reduce domination. With the objective to ensure freedom as non-domination the democratic process should, ideally, include all those and only those that will be dominated if they are not included and that will not be dominated if they are included. Recall from above that freedom as nondomination is not (primarily) about preventing interference but about preventing uncontrolled or arbitrary interference where interference is taken to involve restriction of the choice of a person. The choice of a person is restricted when an option is objectively or cognitively removed or replaced. Your choice is objectively restricted if an option is removed or if an option is replaced. Your choice is cognitively restricted if you perceive that an option is removed or replaced (Pettit 2012, p. 46). I interfere with you if I restrict your choice in any of these respects. The state interferes with you if the state's use of political power removes or replaces options. You are affected by the state's use of political power if this use of political power removes or replaces options. This is admittedly not how 'affected' is usually understood in the literature on the all-affected principle. Being affected is usually understood as having an affected interest (Arrhenius 2005; Goodin 2007). The neo-republican understanding of being affected seems, however, to fit perfectly well with the basics of the all-affected principle. In its general form 'being affected' could be defined as being 'better or worse off' (Miller 2009). Better or worse off could be conceptualized in terms of interests or, as suggested here, in terms of available options.

Political decisions restrict people's choices. Freedom as non-domination is reduced if political decisions are uncontrolled by those whose choices are restricted. Could the all-affected principle be formulated so that those whose choices are restricted by a political decision are included? It seems that it could without stretching the concept. All those whose choices are restricted (removed, replaced) by political decisions are relevantly affected and should therefore be included in the group of people with influence and control over political decisions. ${ }^{11}$

This is a specification of when the affected party is affected in the relevant sense. The affected party is affected in the relevant sense when the doing of the affecting party leaves the affected party better or worse off in terms of options available. What remains to be specified is what is it that the state does that requires democratic inclusion? In the literature on the all-affected principle there are three versions of the principle - the all actually affected principle, the all possibly affected principle and the all plausibly affected principle - that provide three different answers to this question. In what follows, we will discuss these three and argue that all three fit poorly with the neo-republican theory of democracy. We will conclude this section by suggesting a fourth interpretation that seems to fit better.

\footnotetext{
${ }^{10}$ Why not define relevantly affected in terms of domination? However, this would be inconsistent with defining domination 'by reference to interference' (Pettit 2012, p. 50).

11 Sager (2014, p. 196) rejects the all-affected principle because interests is not what trigger a right to political rights'. The reformulated all-affected principle suggested here is immune to this objection.
} 
The standard actual decision ${ }^{12}$ version implies that all and only those that are better or worse off with the actual decisions of the democratic state should be given influence and control over these decisions-should be included in the demos. Formulated in terms of interference, this principle requires inclusion of all those and only those that are actually interfered with. From the perspective of the neorepublican conception of democracy, this principle is both over-inclusive-it requires inclusion of people that are not vulnerable to domination even when they are not included-and under-inclusive-it requires exclusion of people that are vulnerable to domination.

The actual affected version is over-inclusive since it does not distinguish between intentional and unintentional interference. In order to lessen your freedom, interference needs, Pettit (2012, p. 49) argues, to be intentional or quasi-intentional: where interference is intentional (or quasi-intentional) if and only if the interferer has a choice not to interfere. The democratic state interferes in the relevant sense if and only if not interfering is an available option-i.e. if and only if the democratic state could have refrained from interfering but chose to interfere. This misfit between the actual decision version and neo-republicanism is easily avoided.

Whether a political decision intentionally or unintentionally affects someone is usually not considered relevant in determining who is relevantly affected. It is possible, however, to incorporate this aspect in our interpretation of the actual decision version. In that case, those and only those intentionally or quasiintentionally interfered with are relevantly affected. Moreover, it is not just possible to incorporate this aspect, it makes the principle more attractive also from other perspectives. With this reformulation, the actual decision version does not require inclusion of those that are accidently affected, which has been considered an unreasonable feature of the all-affected principle (Beckman 2008). ${ }^{13}$ The result is to avoid over-inclusion in the sense of granting political rights to people that are not dominated when not included. The principle remains under-inclusive, however.

That the actual decision version of the principle requires inclusion of all those who are intentionally interfered with does not imply that it includes all those that are vulnerable to uncontrolled interference. Recall that what is distinctive about the neo-republican conception of freedom is that the freedom of an agent A is not only restricted if A's choices are restricted by another agent B, but also if $\mathrm{B}$ has the power to restrict A's choices that is beyond A's control. If the all-affected principle includes those and only those that are actually affected it fits poorly with this crucial aspect of the neo-republican conception of freedom. The actual decision account of all-affected would fit better with the liberal conceptions of freedom as noninterference or freedom as non-frustration. Since it fails to account for instances of domination without interference, the actual decision version of the all-affected principle should be rejected.

The possible decision version defended by Goodin (2007) seems more promising. This principle requires inclusion of 'anyone who might possibly be affected by any

\footnotetext{
12 The terminology is Goodin's (2007).

${ }^{13}$ Intentional interferences are not accidental. Accidental interferences are unforeseen and therefore unintended in the sense of not leaving the interferer with the choice whether to interfere or not.
} 
possible decision arising out of any possible agenda' (Goodin 2007, p. 55). Formulated as a neo-republican principle of inclusion, it would include not only those actually interfered with but all those that the state could possibly interfere with. The neo-republican motive behind reformulating the principle in this way would be that the affecting party (the democratic state) makes the affected party better or worse off in terms of available options not only by interfering but also by refraining from interfering.

The neo-republican conception of freedom appears sensitive to possible interference: implying that $\mathrm{A}$ is unfree if $\mathrm{B}$ has the means to possibly interfere with A. It has indeed been argued that this is the neo-republican position (Goodin and Jackson 2007, p. 251). If this is how freedom as non-domination should be interpreted, this speaks in favor of the possible decision version of the all-affected principle. If it is true that all those that the state could possibly interfere with are dominated if not given democratic control over state interference, then all those that the state could possibly interfere with should be given democratic control over state interference.

Upon closer examination, it turns out that this is not what freedom as nondomination requires. From the perspective of freedom as non-interference, freedom is reduced by actual interference. From the perspective of freedom as nondomination, freedom is reduced by subjection to actual alien control. According to the abovementioned characterization, freedom is lessened by subjection to possible alien control. The neo-republican conception of freedom as non-domination differs from the liberal conceptions of non-frustration and non-interference in that it makes freedom/unfreedom insensitive to the preferences of both the agent A that could interfere and the agent B that could be interfered with. Freedom as non-frustration is sensitive to the preferences of both A and B. Freedom as non-interference is sensitive to the preferences (action) of agent $\mathrm{A}$ but insensitive to the preferences of agent B. Freedom as non-domination is sensitive to the position of A and B. B is dominated by $\mathrm{A}$ if, and only if, $\mathrm{A}$ is in a position to dominate $\mathrm{B}$. For a conception of freedom to take into account not only actual and available interference but also possible interference it will have to be insensitive not only to the preferences and actions of agent $\mathrm{A}$ and agent $\mathrm{B}$ but also to the position of agent $\mathrm{A}$ and agent $\mathrm{B}$. Interference is possible if $\mathrm{A}$ is in a position to interfere with $\mathrm{B}$ or if $\mathrm{A}$ could be in a position to interfere with $\mathrm{B}$. The neo-republican conception of freedom as nondomination implies that the freedom of $\mathrm{B}$ is reduced if and only if $\mathrm{A}$ is in a position to interfere with B. From the perspective of freedom as non-domination it is an important difference between the possibility that a powerful agent $\mathrm{A}$ will interfere with an agent $\mathrm{B}$ and the possibility that a powerless agent $\mathrm{A}^{*}$ will become powerful and interfere with B (Pettit 2008a, p. 218).

The possible decision version is over-inclusive since it requires inclusion not only of those that the democratic state is in a position to interfere with but also of those that the state is possibly in a position to interfere with. The principle is insensitive to the difference between what is actually and what is possibly within state control. The actual decision version is overly sensitive to what the state does, whereas the possible decision version is overly insensitive to what the state is in a position to do. 
The plausible decision version of the all-affected principle introduced by Owen (2012) seems to offer a middle way here. ${ }^{14}$ The plausible decision version is more inclusive than the actual decision version but less inclusive than the possible decision version. Following this version of the all-affected principle, what should determine inclusion and exclusion is not what the affecting agent will do or what the affecting agent could possibly do but what it is plausible to suppose that the affecting agent will do (Owen 2012, pp. 133-134). Formulated in terms of interference, the plausible decision version would require inclusion of all and only those that it is plausible to suppose that the state will interfere with. Owen (2012, p. 134) suggests a distinction between real and notional options where notional options are options that the democratic state has the capacity to do while real options are options 'compatible with the nexus of purposes, functions and capacities constitutive of a polity's decision-making in the given circumstances and history of its agency'. The neo-republican rationale behind this move would in part be similar to the neo-republican rationale behind the possible decision version suggested above; namely that the affected party is better or worse off in the relevant sense not only when the affecting agent removes or replaces options but also when the affecting agent abstains from removing or replacing options. Instead of taking 'refraining' to mean 'refrain from doing what is possible' we take 'refraining' to mean 'refrain from doing what is plausible'. The affecting agent refrains in the relevant sense when the affecting agent does not do something that it is plausible to suppose that it would do.

The distinction between notional and real options suggested by Owen is arguably important when determining what state interference is probable. But is it important when determining what the state is in the position to do? Arguably it is not, at least not if it is true that the state has the capacity to do what is notional and not only what is real. What is important in determining who is dominated by the state's use of public power is what the state is in a position to do and not what the state is likely to do.

Fortunately, it is possible to reformulate the all-affected principle so that it avoids the problems associated with the formulations discussed so far. Unlike the actual decision version, it should require inclusion of those that the state is in a position to interfere with even if the state does not actually interfere with them. Unlike the possible decision version, it should require exclusion of those that the state could become in a position to interfere with but that the state is not in a position to interfere with. Unlike the plausible decision version, it should require inclusion of those that the state is in a position to interfere with but that it is unlikely that the state will interfere with. Let us refer to this as the available decision version. This version would require inclusion of all and only those that the democratic state is in a position to interfere with. According to the available decision version, the affecting party relevantly affects the affected party if and only if the affected party is better or worse off with the decision taken or with any of the available decisions refrained from taken.

Determining who ought to be included depends both on what the state is in a position to do and on the extent to which any options are either removed or replaced

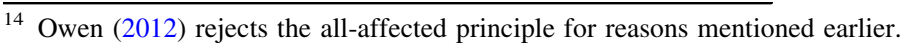


by the state doing what the state is in a position to do. The latter is the focus of the next section whereas the former can be answered by Pettit's (2012, p. 50) remark on the power to interfere. An agent, A, has the power to interfere if A 'has the unvitiated and uninvaded capacity to interfere or not to interfere'. B is dominated by A when interference is equally available to A as non-interference (Pettit 2012, p. 60). This suggests that whether A is likely to remove or replace options available to $\mathrm{B}$ is irrelevant in determining whether $\mathrm{A}$ has the capacity to remove or replace options.

\section{Two Different Neo-Republican Principles of Inclusion}

The upshot is that standard versions of the all-affected principle and the allsubjected principle fit poorly with democracy as devices for securing nondomination. However, a further conclusion is that both principles can be interpreted in line with neo-republican understandings of democracy. For instance, the allsubjected principle can be interpreted as requiring the inclusion of all and only those subjected to legal duties backed up by a capacity to enforce these duties, while the all-affected principle can be interpreted as requiring inclusion of all and only those that the democratic state is in a position to interfere with.

Either principle could substantiate Pettit's claim that all more or less settled residents should be granted rights to democratic influence. Following the neorepublican interpretation of the all-subjected principle, residents within the territory of the state are subjected to legal duties, backed up by a capacity to enforce them, and should therefore be included in the demos. Following the neo-republican interpretation of the all-affected principle, residents in the territory of the state are vulnerable to costless interference by the state and should therefore be included in the demos. The conundrum facing neo-republican democracy is that the all-subjected and the all-affected principle, so interpreted, cannot both be true. The all-subjected principle requires exclusion of people that the state is in a position to interfere with but who are not subject to the institutions of powers of the state in the relevant sense. Conversely, the all-affected principle requires inclusion of people that the state is in a position to interfere with regardless of whether these people are subjected in the relevant sense. The two principles provide conflicting recommendations for how to deal with realworld political problems concerning democratic inclusion and exclusion.

Faced with this incompatibility, there are three options. The first is to endorse the all-subjected principle and to conclude that rights to democratic inclusion extend only to people subjected to legal duties backed up by the capacity of the state to enforce the law. The second option is to endorse the all-affected principle and to conclude that rights to democratic inclusion only extend to people with whom the state is in a position to arbitrarily interfere. The third is to reject both principles. ${ }^{15}$ There are arguments for and against each option.

\footnotetext{
15 A fourth option suggested to us by an anonymous reviewer is to endorse both principles but let them specify two different groups. Hence, the all-affected principle specifies the group of people with editorial control while the all-subjected principle specifies the group of people with authorial control. We reject this option as it leaves no group with democratic control.
} 
The all-subjected principle implies the exclusion of non-residents as they are not subjected to legal duties backed up by the state's capacity to enforce them. Clearly, the interests of some non-residents may be greatly affected by the decisions made by other governments and parliaments. For example, the citizens of Great Britain living abroad will be affected by the decision of the British government to leave the European Union (made on the basis of the decision of the people) in referendum. Yet, as the state lacks the means to enforce legal norms beyond its borders, nonresidents do not count as subjects. From a neo-republican point of view, this conclusion seems unsatisfactory. Recall that an agent, A, dominates another agent, $\mathrm{B}$, if $\mathrm{A}$ has the power to interfere without cost in the choices of B. It seems obvious that democratic states have the power to interfere with non-residents by, for example, polluting their environment or by subjecting them to economic pressure. The latter is an example of domination invoked by Pettit (2010, p. 77). Democratic decisions have extra-territorial impact that non-residents are unable to control. The state is consequently able to dominate non-residents even though they are not subjects.

Nonetheless, it is not evident that democratic inclusion is the appropriate response to the risk of dominating non-residents. Non-residents living in what Pettit (2010) refers to as representative states are less vulnerable to domination by other states. The representative state that they live in has the power to contest decisions made by other states on their behalf. The point is that democratic inclusion is called for only when required to counter domination. Symmetry between degrees of interference and means for the protection against interference is the operating principle. The state has virtually unlimited powers to control residents. Therefore, residents should be granted virtually unlimited powers to control the state. By contrast, the capacity of the state to control non-residents is significantly circumscribed by the powers of other states and the international order (Thomas, 2015). Therefore, non-residents should be granted only limited powers to control foreign states.

A similar point can be made concerning the all-affected principle. It may not seem that the all-affected principle admits of any distinction between residents and non-residents and that both should be included to the extent that they are affected. Yet, the state's means to affect residents clearly outpaces the state's means to affect non-residents. Again, given that non-residents are situated within the borders of other states, the ability of states to enact policy that affects non-residents is to some extent limited. State institutions have unlimited capacity of interference within its jurisdictional borders but only limited capacity of interference outside its jurisdictional borders. Unless included, residents would be severely dominated. By contrast, non-residents would not be severely dominated unless included, because the state does not have the capacity to exercise control over non-residents to the same extent (see further Sager 2014, p. 197).

For these reasons, both principles of inclusion can be rendered coherent with neorepublican aims and aspirations. Yet, the claim that the all-affected principle should be revised to apply only to the residents in the territory of the state evidently gainsays the original motivations of this principle. Advocates of the all-affected principle typically emphasize the significance of trans-national interdependencies 
and the need for forms of democratic structures and modes of participation beyond the state. The neo-republican modification of the all-affected principle does not seem to make sense of it. For this reason, we should conclude that the all-subjected principle represents a more plausible version of what ought to be the neo-republican principle of democratic inclusion.

Acknowledgements We are grateful for helpful comments on earlier versions of this paper from Eva Erman and the participants in the political theory group at the Department of Political Science, Stockholm University.

Open Access This article is distributed under the terms of the Creative Commons Attribution 4.0 International License (http://creativecommons.org/licenses/by/4.0/), which permits unrestricted use, distribution, and reproduction in any medium, provided you give appropriate credit to the original author(s) and the source, provide a link to the Creative Commons license, and indicate if changes were made.

\section{References}

Abizadeh, Arash. 2008. Democratic theory and border coercion: No right to unilaterally control your own borders. Political Theory 36 (1): 37-65.

Abizadeh, Arash. 2010. Democratic legitimacy and state coercion: A reply to David Miller. Political Theory 38 (1): 121-130.

Anderson, Scott A. 2010. The enforcement approach to coercion. Journal of Ethics \& Social Philosophy 5 (1): $1-31$.

Arrhenius, Gustaf. 2005. The boundary problem in democratic theory. In Democracy unbound: Basic explorations, ed. Folke Tersman, 14-29. Stockholm: Department of Philosophy.

Beckman, Ludvig. 2008. Democratic inclusion, law, and causes. Ratio Juris 21 (3): 348-364.

Beckman, Ludvig. 2014. The subjects of collectively binding decisions: Democratic inclusion and extraterritorial law. Ratio Juris 27 (2): 252-270.

Benton, Meghan. 2014. The problem of denizenship: A non-domination framework. Critical Review of International Social and Political Philosophy 17: 49-69.

Blunt, Gwilym David. 2015. On the source, site and modes of domination. Journal of Political Power 8 (1): 5-20.

Dagger, Richard. 2002. Republican citizenship. In Handbook of citizenship studies, ed. Engin F. Isin, and Bryan S. Turner, 145-157. London: SAGE publications.

Erman, Eva. 2014. The Boundary Problem and the Ideal of Democracy. Constellations 21: 535-546.

Fine, Sarah. 2014. Non-domination and the ethics of migration. Critical Review of International Social and Political Philosophy 17 (1): 10-30.

Goodin, Robert E., and Frank Jackson. 2007. Freedom from fear. Philosophy \& Public Affairs 35 (3): 249-265.

Goodin, Robert E., and Ana Tanasoca. 2014. Double voting. Australasian Journal of Philosophy 92 (4): $743-758$.

Goodin, Robert E. 2007. Enfranchising all affected interests, and its alternatives. Philosophy \& Public Affairs 35 (1): 40-68.

Hayek, F. A. 1973. Law, legislation and liberty 2 vols, vol. 1. Chicago, IL: The University of Chicago press.

Hobbes, Thomas. 1994 [1668]. Leviathan. Indianapolis IN and Cambridge: Hackett Publishing Company.

Hovdal-Moan, Marit. 2014. Unequal residence statuses and the ideal of non-domination. Critical Review of International Social and Political Philosophy 17 (1): 70-89.

Hughes, Robert C. 2013. Law and coercion. Philosophy Compass 8 (3): 231-240.

Jacob, Daniel. 2015. Every vote counts: Equality, autonomy, and the moral value of democratic decisionmaking. Res Publica 21 (1): 61-75.

López-Guerra, Claudio. 2012. Enfranchising minors and the mentally impaired. Social Theory and Practice 38 (1): 115-138. 
Lubell, Noam. 2010. Extraterritorial use of force against non-state actors. New York, NY: Oxford University Press.

Macedo, Stephan. 2006. Universal jurisdiction national courts and the prosecution of seriouse crimes under international law. Pennsylvania: University of Pennsylvania press.

Miller, David. 2009. Democracýs domain. Philosophy \& Public Affairs 37 (3): 201-228.

Miller, David. 2010. Why immigration controls are not coercive: A reply to Arash Abizadeh. Political Theory 38 (1): 111-120.

Morris, Christopher W. 2012. State coercion and force. Social Philosophy and Policy 29 (01): 28-49.

Näsström, Sofia. 2011. The Challenge of the All-Affected Principle. Political Studies 59: 116-134.

Owen, David. 2012. Constituting the polity, constituting the demos: On the place of the all affected interests principle in democratic theory and in resolving the democratic boundary problem. Ethics \& Global Politics 5 (3): 129-152.

Owen, David. 2014. Republicanism and the constitution of migrant statuses. Critical Review of International Social and Political Philosophy 17 (1): 90-110.

Peacock, J. G. A. 1995. The ideal of citizenship since classical times. In Theorizing citizenship, ed. Roland Beiner. New York, NY: SUNY Press.

Pettit, Philip. 1997. Republicanism: A theory of freedom and government. Oxford: Clarendon.

Pettit, Philip. 2006. Democracy, national and international. The Monist 89 (2): 301-324.

Pettit, Philip. 2007. Free persons and free choices. History of Political Thought 28 (4): 709-718.

Pettit, Philip. 2008a. Freedom and probability: A comment on Goodin and Jackson. Philosophy \& Public Affairs 36 (2): 206-220.

Pettit, Philip. 2008b. Republican freedom: Three axioms, four theorems. Republicanism and Political Theory 104: 45-56.

Pettit, Philip. 2010. A republican law of peoples. European Journal of Political Theory 9 (1): 70-94.

Pettit, Philip. 2011. The instability of freedom as noninterference: The case of Isaiah Berlin. Ethics 121 (4): $693-716$.

Pettit, Philip. 2012. On the people's terms: A republican theory and model of democracy. Cambridge: Cambridge University Press.

Rostbøll, Christian F. 2015. Non-domination and democratic legitimacy. Critical Review of International Social and Political Philosophy 18 (4): 424-439. doi:10.1080/13698230.2015.1033862.

Sager, Alex. 2014. Political rights, republican freedom, and temporary workers. Critical Review of International Social and Political Philosophy 17 (2): 189-211.

Saunders, Ben. 2011. Immigration. Rights and Democracy. Theoria 58 (129): 58-77.

Schuppert, Fabian. 2014. Freedom, Recognition and Non-Domination. A Republican Theory of (Global) Justice. Dordrecht: Springer.

Shapiro, Ian. 2003. The state of democratic theory. Princeton, NJ: Princeton University Press.

Valentini, Laura. 2014. No Global Demos, No Global Democracy? A Systematization and Critique. Perspectives on Politics 12: 789-807.

Urbinati, Nadia. 2012. Competing for liberty: The republican critique of democracy. American Political Science Review 106 (3): 607-621. 